\title{
Analisis Tingkat Kinerja Kawasan Ekonomi Terpadu Di Kota Samarinda
}

\author{
Muthia Nur Ipmasyari, Ajeng Nugrahaning Dewanti, dan Rossana Margaret Kadar Yanti \\ Perencanaan Wilayah dan Kota, Jurusan Teknik Sipil dan Perencanaan \\ Institut Teknologi Kalimantan \\ e-mail: 08151027@itk.ac.id
}

\begin{abstract}
Abstrak-Kota Samarinda ditetapkan sebagai pusat pertumbuhan ekonomi perdagangan dan jasa regional terpenting di Provinsi Kalimantan Timur dengan konsep Kawasan Pengembangan Ekonomi Terpadu (RTRW provinsi Kalimantan Timur 2016 - 2036). Kebijakan program Kawasan Pengembangan Ekonomi Terpadu didukung dengan pengaruh tingkat kinerja kawasan ekonoomi sebagai penggerak pertumbuhan ekonomi di Kota Samarinda serta faktor eksternal yang dapat memengaruhi keberadaan kawasan ekonomi terpadu. Namun, hingga saat ini kinerja kawasan ekonomi terpadu yang ada belum terealisasi secara optimal. Oleh karena itu, tujuan penelitian ini adalah untuk menganalisis tingkat kinerja kawasan ekonomi terpadu terhadap pertumbuhan ekonomi berdasarkan persepsi responden terpilih. Metode yang digunakan dalam penelitian ini yaitu metode analisis Skala Likert untuk mengukur tingkat kinerja Kawasan Pengembangan Ekonomi Terpadu di Kota Samarinda. Berdasarkan hasil analisis diketahui bahwa tingkat kinerja kawasan ekonomi terpadu pada 7 indikator pertumbuhan ekonomi menempati skala 1 atau sangat rendah. Sedangkan variabel investasi menempati skala 2 atau rendah. Dapat diketahui jika tingkat kinerja kawasan ekonomi terpadu bagi pertumbuhan perekonomian di Kota Samarinda belum terealisasi.
\end{abstract}

Kata Kunci- Kawasan Pengembangan Ekonomi Terpadu, Kinerja, Pertumbuhan

\section{PENDAHULUAN}

$\mathrm{K}$ AWASAN Pengembangan Ekonomi Terpadu merupakan suatu program pengembangan kawasan untuk mengurangi kesenjangan antar daerah serta meningkatkan pola pergerakkan kegiatan ekonomi yang diandalkan (Rencana Pembangunan Jangka Panjang Tahun 2005 - 2025). Badan Pengelolaan Kawasan Pengembangan Ekonomi Terpadu (2018) mengemukakan tujuan dari dilaksanakannya program Kawasan Pengembangan Ekonomi Terpadu yaitu sebagai wadah andalan penggerak pembangunan ekonomi dan meningkatkan peranan perekonomian daerah, khususnya untuk meningkatkan produktifitas ekonomi serta meningkatkan berbagai indikator ekonomi seperti PDRB, tingkat kesejahteraan masyarakat, serta produktifitas potensi sumber daya manusia dan alam.

Kurniawati (2012) menyebutkan jika realisasi dari program Kawasan Pengembangan Ekonomi Terpadu yang baik adalah mampu memicu dan meningkatkan kegiatan pembangunan perekonomian, seperti pengendalian dan pengawasan pembangunan industri, pengoptimalan perdagangan dan jasa, pengembangan sarana, prasarana, dan fasilitas ekonomi. Fungsi dari pengoptimalan tersebut agar fokus pengembangan dapat dilakukan pada pengembangan ekonomi di sektor primer, pengembangan ekonomi di sektor sekunder, dan pengembangan ekonomi di sektor tersier (Kurniawati, 2012).

Namun penerapan program kawasan ekonomi terpadu di Kota Samarinda belum terealisasikan secara maksimal sesuai dengan tujuan dari adanya program tersebut (Dinas Pekerjaan Umum dan Penataan Ruang Kota Samarinda, 2018). Hal tersebut ditunjukkan melalui indeks perekonomian di Kota Samarinda, salah satunya tingkat kemiskinan yang terus mengalami peningkatan. Sejak tahun 2015, garis kemiskinan di Kota Samarinda mencapai 38,95 ribu jiwa dengan angka garis kemiskinan 533.932 rupiah, hingga pada tahun 2018 meningkat menjadi 40,011 ribu jiwa dengan angka garis kemiskinan sebesar 594.645 rupiah (Samarinda Dalam Angka, 2019). Permasalahan ekonomi di Kota Samarinda juga terlihat dari laju pertumbuhan produk domestik regional bruto yang tidak mengalami perkembangan sejak tahun 2017. PDRB Kota Samarinda pada tahun 2017 hanya mencapai angka 280.81. PDRB tersebut lebih kecil dibandingkan dengan Kutai Kartanegara sebesar 425.74, Kabupaten Nunukan sebesar 340.68, Kabupaten Malinau sebesar 349.54, dan Kota Balikpapan yang mencapai 280.84 (Indeks Produk Domestik Regional Bruto Provinsi Kalimantan Timur, 2019).

Meskipun program kawasan pengembangan ekonomi terpadu telah dianggap menempati posisi strategis, namun hingga saat ini program Kawasan Pengembangan Ekonomi Terpadu belum dapat memberikan kontribusi bagi perekonomian di Kota Samarinda sesuai dengan tujuan pembentukan program tersebut. Seperti yang dijelaskan pula oleh Bapak Hendri (2018), hingga tahun 2018 program Kawasan Pengembangan Ekonomi Terpadu belum mampu menjadi penggerak pertumbuhan ekonomi, baik dari PDRB, peningkatan lapangan pekerjaan, pengoptimalan peranan antar sektor ekonomi serta peningkatan kerjasama antar kawasan. Berdasarkan hal tersebut dapat terlihat jika ada perbedaan antara tujuan program kawasan pengembangan ekonomi terpadu dengan kondisi riil di Kota Samarinda. Oleh karena itu, perlu dilakukan analisis tingkat kinerja kawasan ekonomi terpadu terhadap pertumbuhan ekonomi di Kota Samarinda guna mengoptimalkan peranan Kota Samarinda sebagai pusat pertumbuhan ekonomi daerah.

\section{METODE PENELITIAN}

\section{A. Variabel Penelitian}

Subjek penelitian adalah Program Kawasan Ekonomi Terpadu yang dikemukakan dalam aspek - aspek, yaitu: (1) 
Keterlibatan Masyarakat (STBM); (2) Pemerintah; dan (3) Potensi Ekonomi Wilayah.

Purposive Sampling merupakan teknik pengambilan sampel sumber data berdasarkan pertimbangan tertentu. Alasan menggunakan teknik Purposive Sampling adalah karena tidak semua sampel memiliki kriteria yang sesuai dengan fenomena yang diteliti. Teknik purposive sampling memilih sekelompok subyek berdasarkan karakteristik tertentu yang dinilai memiliki keterkaitan dengan ciriciri atau karakteristik dari populasi yang akan diteliti. Karakteristik ini sudah diketahui oleh peneliti. Sehingga mereka hanya perlu menghubungkan unit sampel berdasarkan kriteria-kriteria tertentu (Sugiyono, 2016). Objek penelitian yang dimaksud dapat berupa makhluk hidup, benda - benda, sistem, prosedur dan fenomena. Sampel merupakan bagian dari populasi, dimana sampel tersebut dapat merepresentasikan populasi. Berdasarkan hal tersebut, populasi penelitian dalam penelitian ini ialah seluruh responden dinas pemerintah yang relevan, paham dan mengetahui kondisi kawasan ekonomi terpadu secara teknis di Kota Samarinda. Berdasarkan buku Prosedur Penelitian oleh Arikunto (2010:18) menjelaskan bahwa syarat - syarat yang harus dipenuhi dalam menentukan sampel berdasarkan tujuan tertentu, yaitu:

1. Pengambilan sampel harus didasarkan atas ciri - ciri, sifat - sifat, atau karakteristik tertentu, yang merupakan ciri - ciri pokok populasi;

2. Subjek yang diambil sebagai sampel benar - benar merupakan subjek yang paling banyak mengandung ciri - ciri pada populasi;

3. Penentuan karakteristik populasi dilakukan dengan cermat di dalam studi pendahuluan; Pada penelitian ini penentuan sampel penelitian digunakan untuk menjawab pertanyaan penelitian pada sasaran pertama dan kedua. Alasan penggunaan teknik purposive sampling adalah karena tidak semua sampel memiliki kriteria yang sesuai dengan fenomena yang diteliti. Oleh karena itu, unit sampel yang dihubungi disesuaikan dengan kriteria kriteria tertentu yang diterapkan berdasarkan tujuan penelitian atau permasalahan penelitian. Adapun kriteria sampel responden untuk menjawab sasaran pertama penelitian ini adalah sebagai berikut:

1. Responden memiliki tupoksi pekerjaan pada bidang perekonomian daerah Kota Samarinda;

2. Responden menangani secara langsung program kawasan ekonomi terpadu dan mengetahui kondisi kawasan ekonomi terpadu;

3. Responden merupakan salah satu pemangku kebijakan pada program kawasan ekonomi terpadu.

Penelitian ini menggunakan rancangan penelitian yang bersifat campuran (kuantitatif - kualitatif). Mixed methods research atau metode penelitian campuran berfokus pada pengumpulan dan analisis data serta memadukan antara data kuantitatif dan data kualitatif, baik dalam single study (penelitian tunggal) maupun series study (penelitian berseri) dengan teknik sampling. Data dikumpulkan dengan metode observasi, wawancara, dan pencatatan dokumen yang hasilnya dianalisis secara deskriptif kualitatif dan deskriptif kuantitatif. Dalam menganalisis tingkat kinerja kawasan ekonomi terpadu, akan dilakukan melalui teknik analisis validitas menggunakan skala pengukuran likert. Analisis ini digunakan untuk memperoleh nilai skala tingkat kinerja kawasan ekonomi terpadu sebagai penggerak pertumbuhan ekonomi di Kota Samarinda pada setiap variabel yang telah ditentukan, meliputi pendapatan nasional riil, pendapatan riil per kapita penduduk, kesejahteraan masyarakat, tenaga kerja, kegiatan ekonomi masyarakat, pendapatan, pengeluaran, dan investasi.

Skala likert merupakan suatu skala pengukuran menggunakan beberapa butir pertanyaan yang pada umumnya bersifat pengukuran sikap, keyakinan, nilai dan pendapat pengguna atau konsumen terhadap suatu pelayanan jasa atau objek (Budiaji, 2003). Pengukuran skor jawaban merupakan nilai jawaban yang akan diberikan oleh responden sehingga perlu dilakukan penentuan skor dari setiap jawaban yang akan diberikan. Setelah melakukan penentuan skor, selanjutnya ditentukan banyaknya jawaban pada tiap pertanyaan yang akan diberikan. Misalnya terdapat 5 atau 7 skala pilihan, maka hal tersebut dimaksudkan jika terdapat pertanyaan susah, maka responden tidak menjawab secara statik. Adapun skor yang diberikan pada penilaian analisis skala likert pada tingkat kinerja kawasan ekonomi terpadu menurut Supranto (2000) sebagai berikut.

Tabel 1.

Skor Penilaian Tingkat Kinerja Kawasan Ekonomi Terpadu

\begin{tabular}{ccc}
\hline Skala & Hasil Akhir & Penilaian \\
\hline 1 & $10 \%-19 \%$ & Sangat \\
& & Rendah \\
2 & $20 \%-39 \%$ & Rendah \\
3 & $40 \%-59 \%$ & Cukup \\
4 & $60 \%-79 \%$ & Tinggi \\
5 & $>80 \%$ & Sangat Tinggi \\
\hline \hline
\end{tabular}

Tabel 2.

Interpretasi Skor Penilaian Tingkat Kinerja Kawasan Ekonomi Terpadu

\begin{tabular}{|c|c|c|}
\hline Skor & Skala & Interpretasi \\
\hline 5 & $\begin{array}{l}\text { Sangat } \\
\text { Baik }\end{array}$ & $\begin{array}{l}\text { Efektif dan Efisien, memberikan dampak atau } \\
\text { perubahan yang signifikan, memberikan kontribusi } \\
\text { bagi peningkatan ekonomi daerah, program } \\
\text { peningkatan yang diterapkan oleh Kawasan } \\
\text { Ekonomi Terpadu berhasil }\end{array}$ \\
\hline 4 & Baik & $\begin{array}{l}\text { Terdapat dampak atau perubahan dalam penerapan } \\
\text { kinerja tersebut, namun mengalami beberapa } \\
\text { permasalahan di dalamnya sehingga perlu adanya } \\
\text { peningkatan dan evaluasi kinerja }\end{array}$ \\
\hline 3 & Cukup & $\begin{array}{l}\text { Kinerja dapat memenuhi tujuan utama dalam } \\
\text { pengembangan ekonomi daerah namun, namun } \\
\text { tingkat pengembangan yang ditunjukkan stagnan } \\
\text { atau kurang terlihat }\end{array}$ \\
\hline 2 & Buruk & $\begin{array}{l}\text { Kinerja kawasan ekonomi terpadu tidak terlihat, } \\
\text { tujuan dari adanya kawasan ekonomi terpadu tidak } \\
\text { tercapai dan tidak terealisasi sehingga tidak } \\
\text { mengalami perubahan apapun }\end{array}$ \\
\hline 1 & $\begin{array}{l}\text { Sangat } \\
\text { Buruk }\end{array}$ & $\begin{array}{l}\text { Kinerja kawasan ekonomi terpadu tidak } \\
\text { memberikan dampak positif, justru dengan adanya } \\
\text { penerapan kinerja kawasan ekonomi terpadu, } \\
\text { pengembangan ekonomi tersebut semakin buruk } \\
\text { dan tidak terus menerus mengalami kemunduran }\end{array}$ \\
\hline
\end{tabular}

Berdasarkan jawaban responden selanjutnya akan diperoleh satu kecenderungan atas jawaban responden tersebut. Maka perhitungan indeks jawaban responden dilakukan dengan rumus sebagai berikut :

$\mathrm{SKOR}=((\mathrm{F} 1 \times 1)+(\mathrm{F} 2 \times 2)+(\mathrm{F} 3 \times 3)+(\mathrm{F} 4 \times 4)$

$$
+(\mathrm{F} 5 \times 5) / 5
$$

Keterangan :

$\mathrm{F} 1=$ frekuensi jawaban responden yang menjawab 1 (Sangat Rendah)

$\mathrm{F} 2=$ frekuensi jawaban responden yang menjawab 2 
(Rendah)

$\mathrm{F} 3=$ frekuensi jawaban responden yang menjawab 3 (Cukup)

$\mathrm{F} 4=$ frekuensi jawaban responden yang menjawab 4 (Tinggi)

F5= frekuensi jawaban responden yang menjawab 5 (Sangat Tinggi)

Berikut adalah urutan proses pencarian skor ideal tertinggi, skor ideal terendah, panjang interval kelas, dan tinjauan kontimum variabel berdasarkan rumus (Riduwan, 2009). Jumlah skor tersebut dimasukkan ke dalam garis kontinum yang pengukurannya ditentukan dengan cara:

Nilai Maksimal $=$ Skor Tertinggi $x$ Soal $x$ Sampel

Nilai Minimum $=$ Skor Terendah $\mathrm{x}$ Soal $\mathrm{x}$ Sampel

$\%$ Skor $=($ Total Skor : Nilai Maksimal $) \times 100$

Angka yang dimasukkan ke dalam rumus persentase di atas merupakan data yang diperoleh dari hasil jawaban responden atas pertanyaan yang diajukan. Hasil perhitungan tersebut kemudian dibandingkan dengan kriteria yang telah ditetapkan. Adapun tahapan untuk mengetahui tingkat kinerja kawasan ekonomi terpadu antara lain:

1. Merekapitulasi jawaban responden yang didapatkan dari hasil kuesioner. Hasil tersebut merupakan penjabaran berapa banyak responden yang memilih jawaban 1 sampai dengan 5;

2. Setelah data kuesioner direkapitulasi, selanjutnya dibuat diagram untuk mengetahui nilai atau persentase dari masing - masing jawaban responden;

3. Melakukan perhitungan indeks jawaban responden dengan menghitung frekuensi jawaban responden terhadap masing - masing skala;

4. Setelah menghitung indeks jawaban responden, selanjutnya jumlah skor yang telah didapatkan dimasukkan pada garis pengukuran tingkat kinerja, meliputi perhitungan nilai indeks maksimal, nilai indeks minimum, dan persentase skor;

Selanjutnya persentase skor yang didapatkan akan disesuaikan terhadap kriteria interpretasi skor yang didapatkan melalui tinjauan teori.

Dalam penelitian ini dilakukan pengambilan sampel melalui teknik purposive sampling untuk menentukan responden dalam penelitian. Purposive Sampling merupakan teknik pengambilan sampel sumber data berdasarkan pertimbangan tertentu. Alasan menggunakan teknik Purposive Sampling adalah karena tidak semua sampel memiliki kriteria yang sesuai dengan fenomena yang diteliti. Adapun kriteria sampel responden untuk menjawab sasaran pertama penelitian ini adalah sebagai berikut:

1. Responden memiliki tupoksi pekerjaan pada bidang perekonomian daerah Kota Samarinda;

2. Responden menangani secara langsung program kawasan ekonomi terpadu dan mengetahui kondisi kawasan ekonomi terpadu;

3. Responden merupakan salah satu pemangku kebijakan pada program kawasan ekonomi terpadu.

Berdasarkan kriteria yang telah ditentukan di atas, selanjutnya dilakukan evaluasi terhadap responden yang akan dipilih berdasarkan tupoksi (tugas, pokok, dan fungsi) setiap Dinas Pemerintahan, antara lain :

Tabel 3.

Tupoksi Responden

\begin{tabular}{lll}
\hline \hline No & Kelompok & Tupoksi \\
& Responden
\end{tabular}

1. Ikut serta dalam proses

perumusan perencanaan kawasan ekonomi terpadu bersama dengan Badan Pengelolaan Kawasan Pengembangan Ekonomi Terpadu

1. Bappeda Kota Samarinda Bidang Prasarana Wilayah

1. Bappeda Kota Samarinda Bidang Prasarana Wilayah

Badan Pengelolaan Kawasan Ekonomi Terpadu Kota

Samarinda Bidang Teknis, Operasi,

Prasarana dan

Sumber Daya Alam

Dinas Pendapatan Kota Samarinda Bidang

Pemeriksaan dan

Pengawasan

Perekonomian

4.

Dinas Perindustrian Kota Samarinda Bidang Pembinaan Usaha Industri

5. Dinas Penanaman Modal dan Pelayanan Terpadu Satu Pintu Kota
2. Berkordinasi dengan seluruh dinas di Kota Samarinda khususnya untuk perekonomian daerah Kota Samarinda

3. Terlibat dalam proses evaluasi pelaksanaan program pembangunan kawasan ekonomi terpadu pada aspek pengembangan ekonomi

4. Pelaksanan dalam penelitian dan pengkajian pengembangan ekonomi daerah di Kota Samarinda

1. Merumuskan dan menyusun kebijakan terkait pengembangan kawasan ekonomi terpadu;

2. Merumuskan segala kebijakan terkait administrasi kawasan ekonomi terpadu

3. Memberikan masukan untuk pengusulan kawasan yang akan ditetapkan sebagai kawasan ekonomi terpadu;

4. Menyiapkan rumusan kebijakan dan strategi nasional untuk mempercepat pembangunan kawasan ekonomi terpadu;

5. Menyiapkan rumusan kebijakan yang diperlukan untuk mendorong dan mempercepat masuknya investasi dunia usaha di kawasan ekonomi terpadu;

6. Menyiapkan fasilitas pelaksanaan kegiatan pembangunan kawasan ekonomi terpadu

1. Merumuskan kebijakan pendapatan daerah dari adanya program kawasan ekonomi terpadu;

2. Pembinaan pajak kegiatan kawasan ekonomi terpadu serta pelayanan umum terkait pendapatan daerah;

3. Mengatur pengendalian dan evaluasi pendapatan dari adanya program kawasan ekonomi terpadu

1. Merumuskan kegiatan dalam upaya peningkatan dan pengembangan kegiatan industri di Kota Samarinda melalui program kawasan ekonomi terpadu

2. Melakukan pendataan kegiatan industri di Kota Samarinda

3. Dapat memberikan informasi bagi pemberi modal terkait perdagangan dan jasa yang ada di Kota

Samarinda bagi calon investor yang akan berinvestasi di kawasan ekonomi terpadu

1. Perumusan dan penyusunan kebijakan dibidang perencanaan dan pengembangan iklim penanaman modal kawasan ekonomi terpadu; 


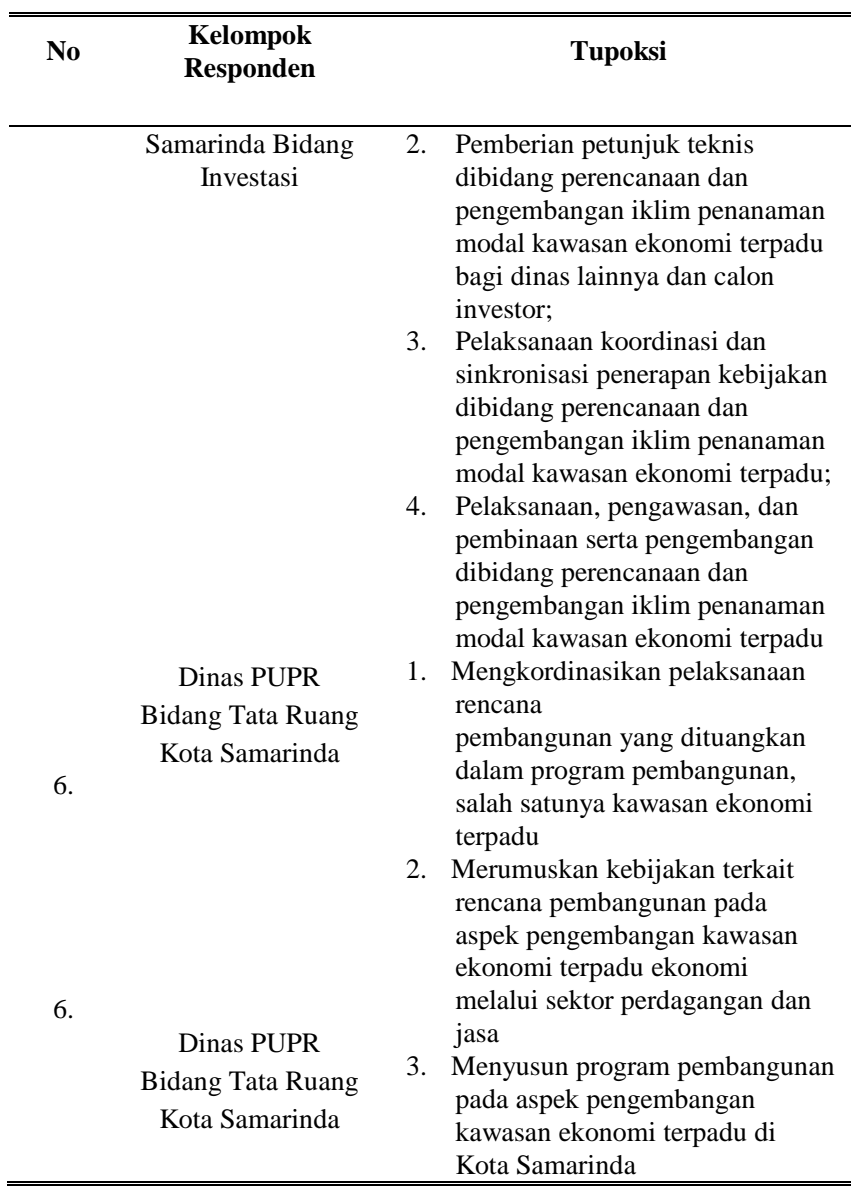

Berdasarkan tupoksi masing - masing responden yang telah ditampilkan di atas serta hasil evaluasi responden yang telah dilakukan, maka dapat diketahui beberapa Dinas Pemerintahan yang akan menjadi responden pada penelitian ini, antara lain:

1. Badan Perencanaan dan Pembangunan Daerah Kota Samarinda; Bidang Prasarana Wilayah;

2. Badan Pengelolaan Kawasan Ekonomi Terpadu Kota Samarinda; Bidang Teknis, Operasi, Prasarana dan Sumber Daya Alam;

3. Dinas Pendapatan Kota Samarinda; Bidang Pemeriksaan dan Pengawasan Perekonomian;

4. Dinas Perindustrian Kota Samarinda; Bidang Pembinaan Usaha Industri;

5. Dinas Penanaman Modal dan Pelayanan Terpadu Satu Pintu Bidang Investasi Kota Samarinda; Bidang Investasi;

6. Dinas Pekerjaan Umum dan Penataan Ruang; Bidang Tata Ruang

\section{HASIL DAN PEMBAHASAN}

\section{A. Pendapatan Domestik Regional Bruto}

Salah satu indikator ekonomi makro yang digunakan untuk melihat hasil pembangunan di suatu daerah adalah PDRB (Produk Domestik Regional Bruto). Hal ini yang memberi gambaran totalitas nilai tambah yang tercipta dari seluruh barang dan jasa akhir yang dihasilkan oleh seluruh unit usaha di suatu daerah dalam satu tahun. Kenaikan jumlah produksi dan harga barang/jasa merupakan faktor utama pendorong kenaikan nilai PDRB Kota Samarinda, terlebih berjalannya otonomi daerah. Perkembangan PDRB atas dasar harga berlaku selama kurun waktu 2014- 2018 di Kota Samarinda menunjukkan tren yang meningkat dan mengalami kenaikan. Selanjutnya disajikan tabel perkembangan dan laju pertumbuhan PDRB di Kota Samarinda sebagai berikut :

Tabel 4.

Perkembangan PDRB dan Laju Pertumbuhan PDRB Kota Samarinda Tahun 2013-2018 (Juta Rupiah)

\begin{tabular}{ccccc}
\hline \hline Tahun & \multicolumn{2}{c}{ PDRB (Juta Rupiah) } & \multicolumn{2}{c}{ Pertumbuhan (\%) } \\
\hline ke & Berlaku & Konstan & Berlaku & Konstan \\
2014 & $44.824 .302,2$ & $37.471 .852,6$ & 8,68 & 4,93 \\
2015 & $48.273 .715,4$ & $39.506 .305,3$ & 7,70 & 5,43 \\
2016 & $50.799 .587,6$ & $39.523 .547,4$ & 5,23 & 0,04 \\
$2017 *$ & $52.334 .150,7$ & $39.733 .062,1$ & 3,02 & 0,53 \\
$2018^{* *}$ & $57.946 .612,2$ & $41.169 .836,6$ & 10,72 & 3,62 \\
\hline \hline
\end{tabular}

*Angka Sementara

**Angka Sangat Sementara

\section{B. Pendapatan Riil Per Kapita}

Berikut adalah gambaran pendapatan riil per kapita atas dasar harga berlaku tahun 2014 - 2018:

Tabel 5.

Agregat PDRB Per Kapita dan Pendapatan Regional Per Kapita Atas Harga Berlaku Tahun $2014-2018$ PDRB Per

$\begin{array}{ccc}\begin{array}{c}\text { Kapita } \\ \text { Harga } \\ \text { berlaku } \\ \text { (Juta Rp) }\end{array} & \begin{array}{c}\text { Pendapatan } \\ \text { Regional Per } \\ \text { Kapita (Ribu } \\ \text { Rp) }\end{array} & \begin{array}{c}\text { Pertumbuhan } \\ \text { PDRB/ } \\ \text { Kapita } \\ (\%)\end{array} \\ 44.824,30 & 57.392,37 & 2,77 \\ 48.273,72 & 60.568,82 & 3,31 \\ 50.799,59 & 62.515,11 & -1,88 \\ 52.334,15 & 68.702,22 & -1,38 \\ 57.946,61 & 63.182,37 & 1,76\end{array}$

Angka Sementara

**Angka Sangat Sementara

Tabel di atas memperlihatkan nilai PDRB perkapita per tahun. Nilai tersebut di dapat dengan cara membagi masingmasing nilai tambah bruto pada setiap tahun dengan penduduk pertengahan tahun. Terlihat bahwa nilai PDRB per kapita Kota Samarinda terbesar terdapat pada tahun 2017 sebesar 68,70 juta sedangkan pada tahun 2018 mengalami penurunan dengan angka PDRB hanya mencapai $63.182,37$

\section{Analisis Tingkat Kinerja Kawasan Ekonomi Terpadu}

Dalam analisis tingkat kinerja kawasan ekonomi terpadu terhadap pertumbuhan ekonomi di Kota Samarinda, perhitungan skala jawaban responden digunakan untuk mendapatkan nilai tingkat kinerja kawasan ekonomi terpadu. Indikator penilaian menggunakan analisis skala likert melalui kuesioner, kemudian dilakukan perhitungan terhadap skor kriterium jawaban responden yang di dalamnya meliputi skala 1 (sangat rendah), 2 (rendah), 3 (cukup), 4 (tinggi), 5 (sangat tinggi). Sehingga dapat dilakukan perhitungan terhadap nilai indeks maksimal, nilai indeks minimal, jarak interval, dan persentase skor yang akan menunjukkan tingkat kinerja kawasan ekonomi terpadu pada tiap variabel pertumbuhan ekonomi.

Berikut disajikan skor yang diberikan pada penilaian analisis skala likert pada tingkat kinerja kawasan ekonomi terpadu menurut Supranto (2000) sebagai berikut.

Tabel 6.

Skor Penilaian Tingkat Kinerja Kawasan Ekonomi Terpadu

\begin{tabular}{ccc}
\hline \hline Skala & Hasil Akhir & Penilaian \\
\hline 1 & $10 \%-19 \%$ & Sangat Rendah \\
2 & $20 \%-40 \%$ & Rendah \\
3 & $41 \%-60 \%$ & Cukup \\
4 & $61 \%-80 \%$ & Tinggi \\
5 & $>81 \%$ & Sangat Tinggi \\
\hline \hline
\end{tabular}

Dengan Skala Likert, variabel yang akan diukur dijabarkan menjadi indikator variabel. Kemudian indikator tersebut dijadikan sebagai titik tolak untuk menyusun item- 
item instrumen yang dapat berupa pertanyaan atau pernyataan. Jawaban setiap item instrumen yang menggunakan Skala Likert mempunyai gradasi dari sangat positif sampai sangat negatif. Selanjutnya, pemberian skor ideal yang merupakan skor yang digunakan untuk menghitung rating scale dan jumlah seluruh jawaban. Untuk menghitung jumlah skor ideal (kriterium) dari seluruh item, digunakan rumus berikut, yaitu:

Skor kriterium $=$ Nilai skala $\mathrm{x}$ Jumlah responden

Jika skor tertinggi adalah 5 dan jumlah responden adalah 10, maka dapat dirumuskan menjadi:

Tabel 7.

Interpretasi Jawaban Responden

\begin{tabular}{|c|c|c|}
\hline Rumus & Skala & Interpretasi \\
\hline $5 \times 10$ & Sangat Baik & $\begin{array}{l}\text { Efektif dan Efisien, memberikan } \\
\text { dampak atau perubahan yang } \\
\text { signifikan, memberikan kontribusi } \\
\text { bagi peningkatan ekonomi daerah, } \\
\text { program peningkatan yang } \\
\text { diterapkan oleh Kawasan Ekonomi } \\
\text { Terpadu berhasil }\end{array}$ \\
\hline $4 \times 10$ & Baik & $\begin{array}{l}\text { Terdapat dampak atau perubahan } \\
\text { dalam penerapan kinerja tersebut, } \\
\text { namun mengalami beberapa } \\
\text { permasalahan di dalamnya } \\
\text { sehingga perlu adanya peningkatan } \\
\text { dan evaluasi kinerja }\end{array}$ \\
\hline $3 \times 10$ & Cukup & $\begin{array}{l}\text { Kinerja dapat memenuhi tujuan } \\
\text { utama dalam pengembangan } \\
\text { ekonomi daerah namun, namun } \\
\text { tingkat pengembangan yang } \\
\text { ditunjukkan stagnan atau kurang } \\
\text { terlihat }\end{array}$ \\
\hline $2 \times 10$ & Buruk & $\begin{array}{l}\text { Kinerja kawasan ekonomi terpadu } \\
\text { tidak terlihat, tujuan dari adanya } \\
\text { kawasan ekonomi terpadu tidak } \\
\text { tercapai dan tidak terealisasi } \\
\text { sehingga tidak mengalami } \\
\text { perubahan apapun }\end{array}$ \\
\hline $1 \times 10$ & Sangat Buruk & $\begin{array}{l}\text { Kinerja kawasan ekonomi terpadu } \\
\text { tidak memberikan dampak positif, } \\
\text { justru dengan adanya penerapan } \\
\text { kinerja kawasan ekonomi terpadu, } \\
\text { pengembangan ekonomi tersebut } \\
\text { semakin buruk dan tidak terus } \\
\text { menerus mengalami kemunduran }\end{array}$ \\
\hline
\end{tabular}

Berdasarkan metode di atas, adapun hasil analisis tingkat kinerja kawasan ekonomi terpadu pada tiap variabel pertumbuhan ekonomi di Kota Samarinda, yaitu:

1) Pendapatan Nasional Riil

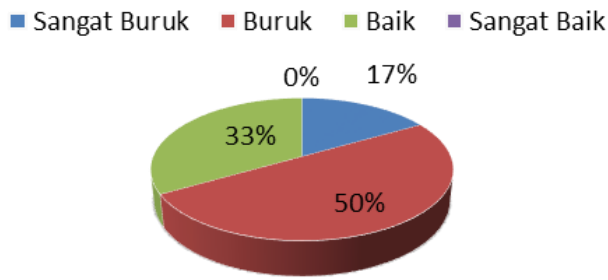

Gambar 1. Persentase Pilihan Responden Pada Kondisi Pengaruh Kawasan Ekonomi Terpadu Terhadap Pendapatan Nasional Riil

Total Skor $=13 / 4=3.25$

Nilai Indeks Maksimal $=4 \times 1 \times 6=24$

Nilai Indeks Minimum $=1 \times 1 \times 6=6$

Persentase Skor $=(3.25 / 24) \times 100 \%=13.5 \%$

Adapun kriteria interpretasi skor dari hasil perhitungan di atas untuk tingkat kinerja kawasan ekonomi terpadu terhadap pendapatan nasional riil berada pada angka $13.5 \%$ yang mengindikasikan jika tingkat kinerjanya sangat rendah atau berada pada skala 1 (sangat buruk) yang jika diinterpretasikan kinerja kawasan ekonomi terpadu tidak memberikan dampak atau kontribusi terhadap pendapatan nasional riil Kota Samarinda. Hal ini didukung pula oleh data pendapatan nasional riil Kota Samarinda, dimana nilai tersebut tidak menunjukkan kenaikan seperti pada tujuan awal dibentuknya program Kawasan Ekonomi Terpadu, namun tetap stagnan dan berada di bawah pendapatan riil nasional Kota atau Kabupaten lain di Provinsi Kalimantan Timur. Saat ini, pendapatan nasional riil Kota Samarinda belum menunjukkan peningkatan yang signifikan, sesuai dengan tujuan dari dibentuknya program kapet serta belum mampu menjadi penggerak pertumbuhan PDRB Kota atau Kabupaten lainnya di Provinsi Kalimantan Timur.

2) Pendapatan Riil Per Kapita Penduduk

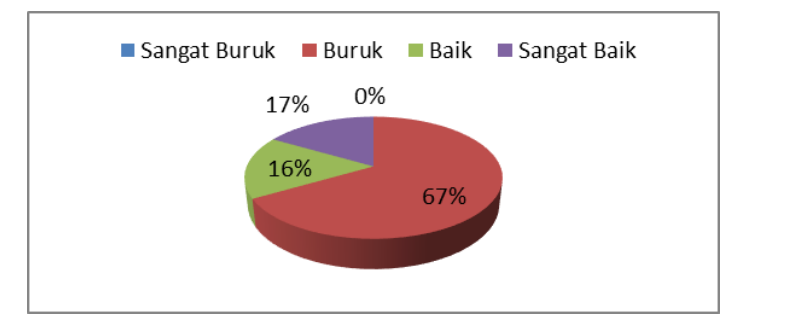

Gambar 2. Persentase Pilihan Responden Pada Kondisi Pengaruh Kawasan Ekonomi Terpadu Terhadap Pendapatan Riil Nasional Penduduk

Total Skor $=15 / 4=3.75$

Nilai Indeks Maksimal $=4 \times 1 \times 6=24$

Nilai Indeks Minimum $=1 \times 1 \times 6=6$

Persentase Skor $=(3.75 / 24) \times 100 \%=15.62 \%$

Adapun kriteria interpretasi skor dari hasil perhitungan di atas untuk tingkat kinerja kawasan ekonomi terpadu terhadap pendapatan nasional riil penduduk berada pada angka $15,62 \%$ yang mengindikasikan jika tingkat kinerjanya sangat rendah atau berada pada skala 1 (sangat buruk) yang jika diinterpretasikan kinerja kawasan ekonomi terpadu tidak memberikan dampak terhadap pendapatan nasional riil per kapita penduduk. Angka pendapatan nasional riil per kapita penduduk mengalami penurunan pada tahun 2018 dan belum menunjukkan peningkatan terutama dari kontribusi kawasan ekonomi terpadu.

3) Kesejahteraan Penduduk

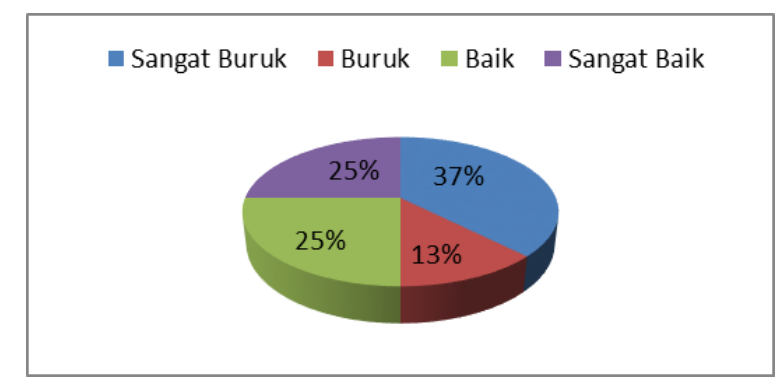

Gambar 3. Persentase Pilihan Responden Pada Kondisi Pengaruh Kawasan Ekonomi Terpadu Terhadap Kesejahteraan Penduduk Kota Samarinda

Total Skor $=13 / 4=3.25$

Nilai Indeks Maksimal $=4 \times 1 \times 6=24$

Nilai Indeks Minimum $=1 \times 1 \times 6=6$

Persentase Skor $=(3.25 / 24) \times 100 \%=13.5 \%$

Adapun kriteria interpretasi skor dari hasil perhitungan di atas untuk tingkat kinerja kawasan ekonomi terpadu 
terhadap kesejahteraan penduduk berada pada angka $13.5 \%$ yang mengindikasikan jika tingkat kinerjanya sangat rendah atau berada pada skala 1 (sangat buruk) yang jika diinterpretasikan kinerja kawasan ekonomi terpadu belum memberikan kontribusi terhadap variabel kesejahteraan masyarakat. Kesejahteraan penduduk merupakan salah satu variabel yang dapat mempengaruhi pertumbuhan ekonomi pada suatu daerah. Namun, angka kesejahteraan penduduk yang diukur dengan Produk Nasional Bruto (Gross National Product) di Kota Samarinda atas dasar harga berlaku selama kurun waktu 2014- 2018 di Kota Samarinda mengalami penurunan.

\section{4) Tenaga Kerja}

$$
\text { - Sangat Buruk } \square \text { Buruk Baik } \square \text { Sangat Baik }
$$

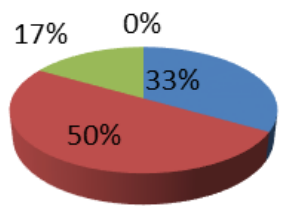

Gambar 4. Persentase Pilihan Responden Pada Kondisi Pengaruh Kawasan Ekonomi Terpadu Terhadap Tenaga Kerja di Kota Samarinda Total Skor $=11 / 4=2,75$

Nilai Indeks Maksimal $=4 \times 1 \times 6=24$

Nilai Indeks Minimum $=1 \times 1 \times 6=6$

Persentase Skor $=(2.75 / 24) \times 100 \%=11.4 \%$

Adapun kriteria interpretasi skor dari hasil perhitungan di atas untuk tingkat kinerja kawasan ekonomi terpadu terhadap tenaga kerja berada pada angka $11,4 \%$ yang mengindikasikan jika tingkat kinerjanya sangat rendah atau berada pada skala 1 (sangat buruk) yang jika diinterpretasikan kinerja kawasan ekonomi terpadu tidak memberikan dampak langsung terhadap peningkatan tenaga kerja. Hal ini juga ditunjukkan dengan kondisi dimana masyarakat lebih banyak bekerja pada sektor lain, serta masih banyak masyarakat yang tidak mengetahui tentang kawasan ekonomi terpadu.

\section{5) Kegiatan Ekonomi Masyarakat}

- Sangat Buruk Buruk Baik $\square$ Sangat Baik

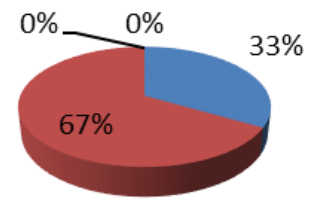

Gambar 5. Diagram; Persentase Pilihan Responden Pada Kondisi Pengaruh Kawasan Ekonomi Terpadu Terhadap Kegiatan Ekonomi Masyarakat di Kota Samarinda

Total Skor $=10 / 4=2.5$

Nilai Indeks Maksimal $=4 \times 1 \times 6=24$

Nilai Indeks Minimum $=1 \times 1 \times 6=6$

Persentase Skor $=(2,5: 24) \times 100 \%=10,4 \%$

Adapun kriteria interpretasi skor dari hasil perhitungan di atas untuk tingkat kinerja kawasan ekonomi terpadu terhadap kegiatan ekonomi masyarakat berada pada angka $10,4 \%$ yang mengindikasikan jika tingkat kinerjanya sangat rendah atau berada pada skala 1 (sangat buruk) yang jika diinterpretasikan saat ini kinerja kawasan ekonomi terpadu terhadap kegiatan ekonomi masyarakat masih belum terlihat atau sangat buruk. Hal ini juga didukung dengan kondisi di Kota Samarinda, dimana belum terdapat pelatihan bagi masyarakat atau kegiatan masyarakat (UKM) yang berkaitan dengan program pengembangan kawasan ekonomi terpadu. 6) Pendapatan

$$
\text { Sangat Buruk Buruk Baik } \square \text { Sangat Baik }
$$

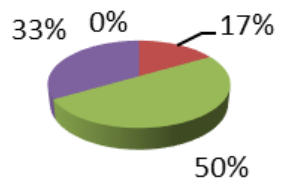

Gambar 6. Diagram; Persentase Pilihan Responden Pada Kondisi Pengaruh Kawasan Ekonomi Terpadu Terhadap Pendapatan di Kota Samarinda

Total Skor $=19 / 4=4.75$

Nilai Indeks Maksimal $=4 \times 1 \times 6=24$

Nilai Indeks Minimum $=1 \times 1 \times 6=6$

Persentase Skor $=(4,75 / 24) \times 100 \%=19,7 \%$

Adapun kriteria interpretasi skor dari hasil perhitungan di atas untuk tingkat kinerja kawasan ekonomi terpadu terhadap pendapatan daerah Kota Samarinda dari kegiatan perdagangan dan jasa berada pada angka 19,7\% atau mendekati angka $20 \%$ yang jika diinterpretasikan berada pada skala 2 atau rendah. Hal ini didukung pula dengan kondisi di lapangan, dimana kinerja kawasan ekonomi terpadu memberikan kontribusi terhadap peningkatkan pendapatan daerah, namun angka yang ditunjukkan dari pendapatan daerah tersebut masih rendah.

\section{7) Pengeluaran}

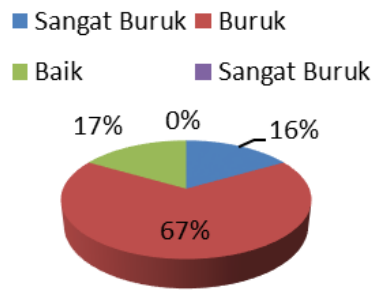

Gambar 7. Diagram; Persentase Pilihan Responden Pada Kondisi Pengaruh Kawasan Ekonomi Terpadu Terhadap Pengeluaran di Kota Samarinda

Total Skor $=12 / 4=3$

Nilai Indeks Maksimal : 4 x 1 × $6=24$

Nilai Indeks Minimum : 1 x 1 x $6=6$

Persentase Skor : $(3 / 24) \times 100 \%=12,5 \%$

Adapun kriteria interpretasi skor dari hasil perhitungan di atas untuk tingkat kinerja kawasan ekonomi terpadu terhadap pengeluaran daerah berada pada angka $12,5 \%$ yang mengindikasikan jika tingkat kinerjanya sangat rendah atau berada pada skala 1 (sangat buruk) yang jika diinterpretasikan kinerja kawasan ekonomi terpadu tidak memberikan kontribusi bagi pengurangan pengeluaran daerah.

8) Investasi

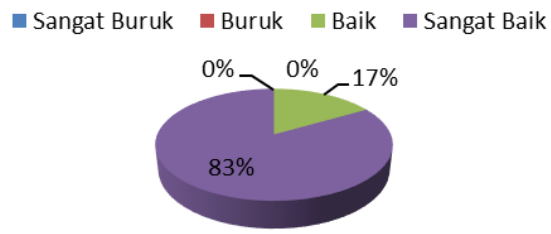


Gambar 8. Diagram; Persentase Pilihan Responden Pada Kondisi Pengaruh Kawasan Ekonomi Terpadu Terhadap Investasi di Kota Samarinda

Total Skor $=23 / 4=5.75$

Nilai Indeks Maksimal : 4 x 1 x $6=24$

Nilai Indeks Minimum : 1 x 1 x $6=6$

Persentase Skor : $(5.75 / 24) \times 100 \%=23.9 \%$

Adapun kriteria interpretasi skor dari hasil perhitungan di atas untuk tingkat kinerja kawasan ekonomi terpadu terhadap pendapatan nasional riil berada pada angka $23.9 \%$ yang mengindikasikan jika tingkat kinerjanya masih rendah atau berada pada skala 2 (buruk) yang jika diinterpretasikan kinerja kawasan ekonomi terpadu memberikan dampak bagi investasi namun masih stagnan pada angka yang sama dan tidak memperlihatkan peningkatan. Dapat diketahui jika penanaman modal asing dan dalam negeri yang masuk ke Kota Samarinda mengalami peningkatkan setiap tahunnya, namun memiliki angka atau nilai terkecil jika dibandingkan dengan kabupaten/kota lain di tahun 2018.

\section{KESIMPULAN}

Tingkat kinerja kawasan ekonomi terpadu terhadap setiap variabel pertumbuhan ekonomi rata - raya berada pada tingkat 1 atau sangat rendah. Adapun variabel yang tingkat pengaruh kinerja kawasan ekonominya berada pada tingkat 1 atau sangat rendah antara lain: 1) Pendapatan Nasional Riil (13,5\%); 2) Pendapatan Riil Penduduk Per Kapita (15,6\%); 3) Kesejahteraan Penduduk (13,5\%); 4) Tenaga Kerja $(11,4 \%)$; 5) Kegiatan Ekonomi Masyarakat $(10,4 \%) ; 6)$ Pengeluaran $(12,5 \%)$. Sedangkan untuk variabel pendapatan dan investasi berada pada tingkat 2 atau rendah dengan nilai pendapatan $(19,7 \%)$ dan investasi $(23,9 \%)$ yang artinya variabel tersebut berpotensi untuk dikembangkan, namun saat ini kondisi investasi yang masuk tetap stagnan dan belum menunjukkan peningkatan yang signifikan.

\section{DAFTAR PUSTAKA}

[1] Arikunto, S. (2010). Prosedur Penelitian Suatu Pendekatan Praktik. Jakarta: Rineka Cipta.

[2] Badan Perencanaan Pembangunan Daerah (BAPPEDA) Provinsi Kalimantan Timur. (2018). "Inventarisasi Data Kawasan Ekonomi Terpadu", Samarinda.

[3] Badan Pengelolaan Kawasan Pengembangan Ekonomi Terpadu. 2018, "Rencana Induk Kegiatan Kawasan Ekonomi Terpadu Sasamba", Samarinda. BP Kawasan Ekonomi Terpadu.

[4] Badan Pusat Statistik Kota Samarinda. 2018, "Samarinda Dalam Angka 2018”, Samarinda: Badan Pusat Statistik Kota Samarinda.

[5] Badan Pusat Statistik Kota Samarinda. 2018. "Agregat PDRB Per Kapita dan Pendapatan Regional per Kapita Atas Harga Berlaku Tahun 2014 - 2018

[6] Budiaji, Weksi. (2013). "Skala Pengukuran dan Jumlah Respon Skala Likert. Jurnal Ilmu Pertanian dan Perikanan, vol. 2, no.2, hal. 127 133.

[7] Budiharsono S. (2005). “Teknik Analisis Pembangunan Wilayah Pesisir dan Laut". Penerbit Pradnya Pramitha. Jakarta.

[8] Dinas Pekerjaan Umum dan Penataan Ruang Provinsi Kalimantan Timur. 2018, "Identifikasi Kondisi Kawasan Ekonomi Terpadu di Kota Samarinda".

[9] Hendri. (2018). "Kawasan Ekonomi Terpadu di Kota Samarinda." Hasil Wawancara Pribadi. 9 April 2018, Badan Pengelolaan Kawasan Ekonomi Terpadu Kota Samarinda.

[10] Kurniawati. (2012). "Analisis Kinerja Peran Kawasan Pengembangan Ekonomi Terpadu Dalam Pengembangan Wilayah Di Kabupaten Bima Nusa Tenggara Barat. Tesis. Program Pascasarjana: Universitas Diponegoro Semarang
[11] Sugiyono. (2010). "Metode Penelitian Kuantitatif Kualitatif". Alfabeta, Bandung.

[12] Sunarto, Riduwan. (2009). Pengantar Statistika Untuk Penelitian Pendidikan. Bogor Agricultural University. Bogor

[13] Supranto. (2000). Pengantar Statistika Untuk Penelitian Pendidikan. Bogor Agricultural University. Bogor 